Neuroepidemiology 2011;37:236-237

DOI: $\underline{10.1159 / 000334606}$

\section{Multiple Sclerosis: Is Prevalence Rising and if So Why?}

Julián Benito-León

Department of Neurology, University Hospital 12 de Octubre, Centro de Investigación Biomédica en Red sobre Enfermedades Neurodegenerativas, and Department of Medicine, Faculty of Medicine, Complutense University, Madrid, Spain

Multiple sclerosis (MS) is a common chronic inflammatory disease of the central nervous system which most frequently appears in early adulthood [1]. Since MS usually affects people in the most active and productive phase of their lives and since the frequency and severity of attacks are largely unpredictable, the impact of the disease on patients and their caregivers' health-related quality of life is important [2-8]. Therefore, it is essential to elucidate the etiology of this disease, and to this end, epidemiological studies are essential.

It has become obvious that the epidemiology of MS has changed over time. Indeed, data over recent years have challenged the traditional view that there is a north-to-south gradient in occurrence in the northern hemisphere and a south-to-north gradient in the southern hemisphere [9]. Furthermore, recent epidemiological studies of MS suggest a trend of increasing disease prevalence and incidence in the same populations worldwide, mainly in women [10-15].

The current study from the rural areas of the Black Sea regions of Turkey reveals a high prevalence of MS in a survey of the general population [16]. The authors examined the prevalence of MS in two rural areas (Kandira and Geyve) near Istanbul, and half the population of Erbaa, all near $40^{\circ}$ north latitude on the Black Sea coast [16]. The study had several strengths, including the large sample size, the design (door-to-door survey) and the methods used for case finding which are carefully described [16]. The most interesting observation was that the prevalence was 51/100,000 and this is of special interest for two reasons [16]. Aside from the fact that little information exists on MS in Turkey, the results suggest that this geographical region is currently a high-risk area for MS. In addition, the results are in line with the prevalence rates reported from other countries in the area such as Greece (prevalence 119.6 per 100,000$)$ [17], Iran $(50.6$ per 100,000$)$ [15] or the Turkish community in Cyprus (55 per 100,000) [18]. The study again demonstrates that the prevalence of MS has increased in the last years.

How can these findings be explained? The Mediterranean basin and Asia have been classically considered as medium- (5-29 per 100,000 population) and low-frequency ( $<5$ per 100,000 pop- ulation) areas, respectively [19]. In the 1970s and early 1980s, the lower prevalence rates could be partially explained by the lack of advanced diagnostic techniques such as magnetic resonance. It is also possible that increasing awareness, either by physicians or patients, could result in the improved diagnosis of mild cases that previously might have gone unnoticed. Moreover, there has been an important change in patients' behavior (i.e. patients tend to seek medical advice more often and with milder symptoms than they did 2 decades ago). Likewise, the increase in prevalence may be due to an improved probability of survival [20]. However, although the quality of the surveys tends to vary between countries, the increase in the prevalence and incidence of MS in the last years worldwide is probably real and not solely due to improved diagnostic techniques or more extensive evaluations. Recent changes in disease incidence and prevalence are likely to be the result of environmental factors that could have been operative in the past few decades. There is evidence to support the view that MS is a complex trait determined by both genetic and environmental factors. Indeed, this disease may be mediated by an autoimmune reaction among susceptible people to a widespread pathogen (Epstein-Barr virus or Candida species?) [21, 22]. Furthermore, the biologically most plausible explanations for a disproportional increase in MS among women in some populations may be the role of vitamin D in MS pathogenesis [14]. Indeed, vitamin D insufficiency or deficiency has been shown to affect T-cell differentiation and regulation, which may influence cellular immune responses against autoantigens and pathogens that have been associated with the etiology of MS [14]. One recent theory is that vitamin D and Epstein-Barr virus may be biologically interacting to increase the risk of MS. This hypothesis is supported by the recent observation that a statistical interaction between infectious mononucleosis prevalence and ultraviolet B radiation could explain $72 \%$ of the variance in MS prevalence across England [23].

In spite of all the recent advances in the search of the involved factors in the etiology of MS, there is still no consensus among researchers. In this way, new epidemiological research regarding etiological factors is necessary for a better approach of the patients, promoting preventive programs for the disease and improving the health-related quality of life of both patients and their caregivers.

\section{Acknowledgment}

Dr. Benito-León is supported by NIH R01 NS039422 from the National Institutes of Health, Bethesda, Md., USA.

\section{References}

1 Benito-Leon J, Martin E, Vela L, Villar ME, Felgueroso B, Marrero C, Guerrero A, Ruiz-Galiana J: Multiple sclerosis in Mostoles, Central Spain. Acta Neurol Scand 1998;98:238-242.

2 Benito-Leon J, Morales JM, Rivera-Navarro J: Health-related quality of life and its relationship to cognitive and emotional functioning in multiple sclerosis patients. Eur J Neurol 2002;9:497-502.

\section{KARGER}

(c) 2011 S. Karger AG, Basel

Fax +41 613061234 E-Mail karger@karger.ch www.karger.com 
3 Morales-Gonzales JM, Benito-Leon J, Rivera-Navarro J, Mitchell AJ: A systematic approach to analyse health-related quality of life in multiple sclerosis: the GEDMA study. Mult Scler 2004;10:47-54.

4 Mitchell AJ, Benito-Leon J, Gonzalez JM, Rivera-Navarro J: Quality of life and its assessment in multiple sclerosis: integrating physical and psychological components of wellbeing. Lancet Neurol 2005;4:556566.

5 Benito-Leon J, Morales JM, Rivera-Navarro J, Mitchell A: A review about the impact of multiple sclerosis on health-related quality of life. Disabil Rehabil 2003;25:1291-1303.

6 Rivera-Navarro J, Morales-Gonzalez JM, Benito-Leon J: Informal caregiving in multiple sclerosis patients: data from the Madrid Demyelinating Disease Group study. Disabil Rehabil 2003;25:1057-1064.

7 Rivera-Navarro J, Benito-Leon J, Oreja-Guevara C, Pardo J, Dib WB, Orts E, Bello M: Burden and health-related quality of life of Spanish caregivers of persons with multiple sclerosis. Mult Scler 2009;15:13471355.

8 Benito-Leon J, Rivera-Navarro J, Guerrero AL, de Las Heras V, Balseiro J, Rodriguez E, Bello M, Martinez-Martin P: The CAREQOL-MS was a useful instrument to measure caregiver quality of life in multiple sclerosis. J Clin Epidemiol 2011;64:675-686.

$\checkmark 9$ Benito-Leon J: Are the prevalence and incidence of multiple sclerosis changing? Neuroepidemiology 2011;36:148-149.

10 Sumelahti ML, Tienari PJ, Wikstrom J, Palo J, Hakama M: Increasing prevalence of multiple sclerosis in Finland. Acta Neurol Scand 2001; 103:153-158.

-11 Houzen H, Niino M, Hata D, Nakano F, Kikuchi S, Fukazawa T, Sasaki $\mathrm{H}$ : Increasing prevalence and incidence of multiple sclerosis in northern Japan. Mult Scler 2008;14:887-892.

12 Warren SA, Svenson LW, Warren KG: Contribution of incidence to increasing prevalence of multiple sclerosis in Alberta, Canada. Mult Scler 2008; $14: 872-879$.

-13 Hirst C, Ingram G, Pickersgill T, Swingler R, Compston DA, Robertson NP: Increasing prevalence and incidence of multiple sclerosis in South East Wales. J Neurol Neurosurg Psychiatry 2009;80:386-391.

14 Sellner J, Kraus J, Awad A, Milo R, Hemmer B, Stuve O: The increasing incidence and prevalence of female multiple sclerosis - a critical analysis of potential environmental factors. Autoimmun Rev 2011;10:495502 .
15 Elhami SR, Mohammad K, Sahraian MA, Eftekhar H: A 20-year incidence trend (1989-2008) and point prevalence (March 20, 2009) of multiple sclerosis in Tehran, Iran: a population-based study. Neuroepidemiology 2011;36:141-147.

16 Türk Börü Ü, Taşdemir M, Güler N, Dilaver Ayık E, Kumaş A, Yıldırım S, Duman A, Sur H, Kurtzke JF: Prevalence of multiple sclerosis: doorto-door survey in three rural areas of coastal Black Sea regions of Turkey. Neuroepidemiology 2011;37:231-235.

17 Papathanasopoulos P, Gourzoulidou E, Messinis L, Georgiou V, Leotsinidis M: Prevalence and incidence of multiple sclerosis in western Greece: a 23-year survey. Neuroepidemiology 2008;30:167-173.

18 Dean G, Aksoy H, Akalin T, Middleton L, Kyriallis K: Multiple sclerosis in the Turkish- and Greek-speaking communities of Cyprus. A United Nations (UNHCR) Bicommunal Project. J Neurol Sci 1997;145: $163-168$.

19 Kurtzke JF: Geographic distribution of multiple sclerosis: an update with special reference to Europe and the Mediterranean region. Acta Neurol Scand 1980;62:65-80.

20 Bronnum-Hansen H, Koch-Henriksen N, Stenager E: Trends in survival and cause of death in Danish patients with multiple sclerosis. Brain 2004; 127:844-850.

-21 Lucas RM, Hughes AM, Lay ML, Ponsonby AL, Dwyer DE, Taylor BV, Pender MP: Epstein-Barr virus and multiple sclerosis. J Neurol Neurosurg Psychiatry 2011;82:1142-1148.

22 Benito-Leon J, Pisa D, Alonso R, Calleja P, Diaz-Sanchez M, Carrasco L: Association between multiple sclerosis and Candida species: evidence from a case-control study. Eur J Clin Microbiol Infect Dis 2010; 29:1139-1145.

23 Ramagopalan SV, Handel AE, Giovannoni G, Rutherford Siegel S, Ebers GC, Chaplin G: Relationship of UV exposure to prevalence of multiple sclerosis in England. Neurology 2011;76:1410-1414.

Dr. Julián Benito-León

Department of Neurology, University Hospital 12 de Octubre

Av. de Córdoba, s/n

ES-28041 Madrid (Spain)

Tel.+34913908600,E-Mail jbenitol@meditex.es 